TRANS · núm. 25.2021

DOSIER $\cdot 133-154$

La presencia del árabe y de sus traducciones en España durante el siglo xvi es muy intensa y presenta varias particularidades. Las traducciones desde el árabe son hechas tanto por musulmanes (mudéjares y moriscos) que van perdiendo progresivamente el uso de la lengua de sus antepasados, como por cristianos. Los objetivos de estos últimos van desde el dominio de los súbditos musulmanes y criptomusulmanes hasta la comprensión del pasado más antiguo de España, incluyendo por supuesto el favorecer la conversión al cristianismo. El objetivo de este trabajo es pasar revista a esa presencia variada de las traducciones del árabe en la España del siglo xvi, señalando qué temas pueden estar aún por estudiar.

PALABRAS CLAVE: árabe, traducción, España, siglo xvi, mudéjares, moriscos, evangelización, pasado.

\title{
Las distintas facetas de las traducciones del árabe en la España del siglo XVI. Apun- tes de un panorama diverso
}

LUIS F. BeRnABÉ PONS
Universidad de Alicante

\section{The Different Angles of the Translations from Arabic in $16^{\text {th }}$ Century Spain. Notes from a Diverse Scene}

The presence of Arabic and its translations in Spain during the $16^{\text {th }}$ century is very intense and presents several peculiarities. The translations from Arabic are carried out both by Muslims (Mudejares and Moriscos), who progressively lose the use of the language of their ancestors, and by Christians. The objectives of Christians' translations from Arabic range from dominating Muslim and crypto-Muslim subjects to understanding Spain's oldest past, as well as, of course, promoting conversion to Christianity. The objective of this work is to review this varied presence of Arabic translations in $16^{\text {th }}$ century Spain, pointing out which topics may still be scrutinized.

KEY WORDS: Arabic, translation, Spain, $16^{\text {th }}$ Century, Mudejares, Moriscos, evangelization, past. 
134 El siglo XVI es la última centuria en la que la presencia de la lengua árabe en España es continua, importante y poliédrica. Con una población hispana de pasado y fe islámicos recién convertida a la fuerza al cristianismo, con relaciones e intereses políticos encontrados con los cercanos países norteafricanos y con el pujante imperio otomano, con una cada vez más creciente voluntad de escrutar el pasado peninsular y asimismo con una decidida voluntad colonizadora del reino de Granada, el árabe se convierte en una lengua de aparición incesante en los estamentos oficiales, en los políticos, en los religiosos y también en las relaciones diarias. La traducción del árabe, por ende, se convierte en una imprescindible herramienta de mediación, conversión, conocimiento y dominio. El objeto de las siguientes páginas será pasar revista, de forma obligadamente resumida, a varios de los aspectos que caracterizan a toda esta serie de traducciones, intentando poner de manifiesto qué puntos oscuros restan aún en nuestro conocimiento.

$\star * * * * * *$

«Cuando despertó, el árabe todavía estaba allí». Esta versión del microrrelato de Augusto Monterroso podría servir bastante bien para la situación de la lengua árabe en la España del siglo XVI. En retroceso en algunos lugares entre quienes debían de ser sus hablantes naturales, los moriscos, la única lengua denostada y perseguida - con oscilaciones- a lo largo del siglo por las autoridades, repudiada su influencia en el castellano por gramáticos y cargada generalmente con el baldón de ser la lengua propia del islam, el árabe sin embargo seguía manteniendo una notable presencia en la vida hispana. No solamente continuaba siendo lengua de uso corriente entre moriscos de Granada, de Valencia y parcialmente de Aragón y Castilla, sino que, además, distintas necesidades administrativas (juicios, verificación de documentos, herencias...), inquisitoriales, políticas y culturales iban a intensificar la necesidad de contar con tra- ducciones y traductores de árabe. Las investigaciones llevadas a cabo en los últimos veinte años han demostrado que la presencia de la lengua árabe y de sus traducciones era mucho más profunda y versátil en los siglos XVI y XVII de lo que pudiera sospecharse en principio. El árabe, además, entraba en España dentro de las discusiones que se están desarrollando en Europa acerca del vernáculo como uno de los elementos de cohesión y regulación social y política (Gilbert, 2018).

En realidad, como en otras ocasiones, los usos derivados de compartimentaciones universitarias empujan a dar por terminada una etapa histórica sin reparar demasiado en que las realidades y consecuencias de esa etapa se extienden mucho más allá de su certificado académico de defunción. Por pura fuerza cronológica, los hablantes monolingües de árabe en 1499 lo seguirán siendo años después, por lo que la necesidad de ser traducidos o interpretados no va a cambiar a causa de los cambios políticos a no ser que las nuevas autoridades necesiten acceder a ellos. Y sus documentos seguirán por mucho tiempo expresados en árabe, en Granada y Valencia mayoritariamente, pero también en Aragón y Castilla (Echevarría y Mayor, 2010). Aunque la guerra de Granada ha finalizado, los hombres que se dedicaron a traspasar las fronteras lingüísticas en la última parte del siglo xv, exeas, alfaqueques, etc., siguen existiendo, acomodando sus vidas a las nuevas situaciones y a las nuevas necesidades. En Valencia, aunque 1521 marca el fin del islam oficial, los moriscos siguen manteniendo el uso hablado y escrito del árabe hasta el momento mismo de la expulsión, por lo que su traducción — por su propia necesidad o por la de los cristianos- seguirá siendo una realidad (Barceló y Labarta, 2009). La misma Inquisición aquí y allá recurre a traductores de árabe para poder entender los libros y papeles que va aprehendiendo en sus distintas causas contra convertidos (Sarmiento, 2015: 2016). 
En este sentido de una realidad multifacética que sigue existiendo y que va tomando nuevos perfiles conforme va pasando el tiempo, la historia de la traducción del y al árabe en el siglo XVI está todavía haciéndose, complementando visiones generales ya publicadas (Cáceres, 2004). Aunque se cuenta ya con un valioso trabajo de perspectiva global sobre la traducción del árabe por Claire Gilbert (Gilbert, 2020), las diferentes realidades que adopta el proceso de traslación oral y/o escrita de una lengua a otra en el primer siglo de oro español aguardan todavía acercamientos a métodos, intenciones y protagonistas. Como señala Salvador Peña (Peña, 2005) una perspectiva narrativa nos permite acercarnos a hombres y obras que protagonizaron los actos de traducción como paso previo a pasar a un análisis estrictamente traductológico que, aunque ya se ha planteado en algunos casos, todavía no se ha hecho de forma sistemática. En las páginas que siguen no puede sino ofrecerse un panorama muy general de las traducciones del y al árabe hechas en la España del siglo XVI, sin posibilidad de abordar la muy variada casuística y los diferentes problemas que ofrece este proceso en la época.

\section{LA TRADUCCIÓN DESDE TU PROPIA ORI- LLA. LAS TRADUCCIONES DE MUDÉJARES Y MORISCOS}

Los mudéjares, luego moriscos, llegan al siglo XVI después de atravesar un complejo proceso político, social y cultural que ha supuesto una erosión en varios aspectos de su vida. Si su vida religiosa se iba viendo progresivamente coartada en lo referido al rito por diversas medidas de las autoridades, en cuanto al manejo de fuentes islámicas se encontraron con el doble problema de la cada vez más acuciante necesidad de obtener algunos libros y autores y de la paulatina pérdida de la lengua árabe en algunas comunidades. Aunque todavía no se ha hecho un mapa completo de ese proceso de pérdida de la competencia en la lengua de sus antepasados ni de la situación real del conocimiento del árabe por parte de las comunidades moriscas en el siglo XVI, sí sabemos que en el XV la situación era en algunos lugares tan ostensible que el recurso a la traducción de su acervo religioso-legal se veía inevitable.

Con este punto de partida, el muftí de Segovia y alfaquí mayor de los moros de Castilla don Içe de Gebir (Wiegers, 1994), tradujo al castellano y adaptó hacia 1462 la ley que los musulmanes de la península llevaban siglos aplicando en el interior de sus aljamas:

\begin{abstract}
Y porque los moros de Castilla, con gran sujeción y muchos tributos y grandes fatigas, han descaecido de sus riquezas y perdido las escuelas del arábigo; y sobre su carescimiento amigos míos de mí trabaron muy mucho afectuosamente, [...] los cuales con tan grande clemencia me rogaron que en romance yo quisiese copilar una tan breve escriptura de nuestra ley y asuna, de todo aquello que todo buen moro debía saber y usar [...]. (Gayangos, 1853: 248).
\end{abstract}

El muftí de Segovia, que había vivido en Saboya años antes la experiencia de la traducción del Corán al castellano por encargo del cardenal Juan de Segovia (Scotto, 2012; Roth, 2014), se plegaba a ese ruego y ofrecía una versión de la ley en lengua romance. También en Valencia se traducirá un compendio similar a comienzos del mismo siglo, el Llibre de la Çuna e Xara, para el señor de Sumacàrcer en Valencia, en un contexto de completa arabización (Barceló, 1989). Ese esfuerzo de traducción de unos materiales religiosos y legales conllevaba igualmente una voluntad de adaptación al medio socio-político circundante. Este Breviario Sunní incluye una especie de prólogo con lo esencial de las normas que debe seguir un musulmán. Como ya señalara Míkel de Epalza (Epalza, 1995), esas normas están pensadas tanto para no ofender 
136 a un posible lector cristiano, como para que un mudéjar pueda reconocerse en ellas.

Naturalmente el hecho de traducir y adaptar al castellano un compendio legal islámico en la Castilla del siglo Xv no necesariamente indica que el árabe se hubiera perdido de forma completa, ni siquiera parcial: indica específicamente que cada vez había menos gente capaz de comprender y usar los textos legales en árabe clásico, aunque podamos sospechar que detrás de eso hubiera igualmente un declive de las «escuelas de arábigo» (García-Arenal, 2010a). En 1414 los miembros de una cofradía de la aljama de Toledo aún escriben las actas de sus sesiones en árabe; evitan usar el fuṣhà aunque entre ellos hay gente a la que se le supone un mayor nivel cultural. El libro de Içe de Gebir, conservado en varios manuscritos y del que seguimos sin tener una edición crítica, es al mismo tiempo, según Harvey, una consecuencia y un inicio: si por un lado da la voz de alarma del deslizamiento hacia el castellano de los mudéjares castellanos, por otro su prestigio da vía y ejemplo a las traducciones de textos islámicos al castellano. El hecho de los ejemplares manuscritos que se conservan procedentes de Aragón indica la influencia que el texto de Segovia pudo tener allí. Como sucede en Castilla, aunque en Aragón se habla normalmente de la pérdida del árabe por parte de los mudéjares tardíos y los moriscos, hay elementos que van en sentido contrario. Julián Ribera, en su trabajo acerca de la enseñanza en al-Ándalus, aportaba en apéndice un documento en árabe en el cual el alumno Muhammad ibn Ibrāhīm ibn 'Abd Allāh Šabațūn de Teruel escribe desde la madrasa sita en la morería de Zaragoza en 1447 (Ribera, 1928). Dicho documento, junto con otros como el que también aporta Ribera a continuación de un tal Muhammad Calavera al-Qurayš̄i escribiendo desde Zaragoza a su maestro en 'Abd Allāh al-Ġāzì en Belchite en el año 900 de la Hégira
(1494-95 d. C.), desmiente la afirmación común de la pérdida del árabe en Aragón. Los manuscritos árabes de datación morisca conservados en Aragón y Castilla - y solo parcialmente estudiados- (Viguera, 1990: 2016; Zanón, 1995) son la prueba fehaciente de ello.

No oculta esto de cualquier forma la existencia de unas traducciones que posiblemente se fueron haciendo cada vez más necesarias en Aragón conforme el siglo XVI avanzaba. Se trata de una literatura islámica que se corresponde con la que se estaba produciendo en árabe, por ejemplo, en Valencia. El proceso de creación de esa literatura aljamiada aragonesa, escrita en castellano con caracteres árabes, tuvo un impulso similar al de Castilla. Los muftíes y alfaquíes de las aljamas detectaron en un momento dado la necesidad de trasvasar al romance seguramente primero textos legales y más tarde textos puramente religiosos para el correcto desempeño de sus funciones y el buen funcionamiento de las comunidades. Fueron ellos mismos en gran medida quienes se pusieron manos a la obra para ofrecer versiones castellanas de sus libros islámicos (Miller, 2008). Lo que había sido antes algo más bien episódico o utilitario, el uso del alifato árabe para expresar otra lengua, se convirtió en una marca confesional asumida. La abundancia de textos legales traducidos como el Kitāb al-Tafrī '>, de Ibn alĞallāb, del Muhtașar de al-Ṭulayțulī, la Risāla de al-Qayrawānī, el texto de Içe de Gebir (Feria, 2001a: 31-71) más otros textos menores aún por identificar es reveladora del interés de los mudéjares y los moriscos en poner en castellano y transmitir este tipo de textos (Carmona, 1992). A través de las traducciones al castellano se intentaba seguir controlando el acervo y la práctica legal islámicos. En un segundo momento, sería el Corán y otros textos religiosos de ortopraxis los que serían traducidos y copiados, para control asimismo de la corrección de la vida religio- 
sa. A estas dos clases de textos les seguirán otros, igualmente necesarios en la vida diaria del creyente que desea seguir en lo posible con su vida de musulmán (Montaner, 1988).

Estas traducciones aljamiadas aragonesas han recibido atención desde antiguo por esa especial naturaleza de tempranos textos islámicos en castellano. Utilizar el castellano en lugar del árabe para tratar de materia islámica no es asunto de poca importancia en esta época, pero es la solución útil para mantener la praxis religiosa con firmeza y, sobre todo, con realismo (Feria, 2001b). De esta forma, mudéjares y moriscos aragoneses van a realizar el esfuerzo de verter unos contenidos islámicos, forjados y desarrollados en árabe, en las estructuras del castellano, lengua que ha crecido semánticamente con el cristianismo. En cierta forma, la traducción de la otredad aquí se sitúa más en el lenguaje que en el objeto y el sujeto de la traducción. Los esfuerzos que pueden observarse en esta aproximación traductora del islam al castellano son interesantes intentos de resolver esa distancia entre religión y lengua. Se trata de traducciones de musulmanes para musulmanes, algo que evidentemente moldea las opciones de traducción por las que se opta, hasta el punto de llegar a crear un idiolecto especial, un «español islámico» reconocible. De manera similar, los moriscos en el exilio magrebí en las primeras décadas del siglo XVII tendrán que hacer elecciones en sus textos religiosos escritos en español para sus correligionarios que no hablaban árabe (Bernabé Pons, 2004b). Los musulmanes aragoneses van a poner especial cautela en la traducción de términos islámicos que pudieran entrañar riesgo de cristianización al traducirlos al castellano. Se trata de un control normativo lingüístico-religioso similar al que llevarán a cabo los catecismos con texto árabe para moriscos y que lleva en los textos aljamiados a términos como almalakes en lugar de «los ángeles», o jalecar en lugar de «crear
(Dios)», o hablar de los musulmanes fisabilados como de los mejores creyentes. Semánticamente árabe-islámicos, morfológicamente castellanos, los vocablos religiosos aljamiados reflejan esta dialéctica entre lo árabe y lo castellano. Únicamente cuando no hay peligro de confusión o de «contaminación» entre religiones el morisco traduce directamente un término árabe por su equivalente castellano. A través de soluciones traductológicas aplicadas regularmente como el uso de calcos lingüísticos, la traslación de estructuras sintácticas árabes o la elección regulada de términos, estas versiones son controladas desde un punto de vista normativo, pero igualmente desde la perspectiva de la recepción de un lector musulmán (López-Morillas, 1990).

Un caso de particular interés lógicamente lo ofrecen las traducciones mudéjares/moriscas del Corán, tanto por las peculiares características del texto dentro del universo del creyente en el islam, como por tratarse de algunas de las traducciones más antiguas del Corán que se conservan (López-Morillas, 2012). En esas traducciones los términos árabes son utilizados de forma insistente - aunque con variacionesallí donde se intuye que hay peligro de deformación de la realidad coránica, y el apego al texto coránico conduce en ocasiones a una literalidad extrema que deriva en una lengua calco (LópezMorillas, 1990). Por otro lado, el traductor quiere evitar cualquier tipo de ambigüedad que pudiera existir derivada del texto original. Lo que en ámbito islámico se solucionaba acudiendo a los comentaristas del Corán — cuyos textos sabemos que circulaban en la España mudéjar-, fue resuelto por los traductores mudéjares/moriscos colocando la exégesis dentro de sus traducciones, bien sustituyendo el término ambiguo por uno de los propuestos por la tradición, bien introduciendo, a modo de glosa, pero sin transición, la explicación que han ofrecido los sabios, 
138 bien anotando el propio texto. De esta forma se ofrece al receptor un texto unívoco, limpio de ambigüedades y opaco a posibles tergiversaciones (Cassassas, 2015).

El aspecto traductológico de los textos coránicos aljamiados ha recibido recientemente una atención renovada después de los estudios de López-Morillas, analizando detenidamente todos estos aspectos y asimismo sus relaciones con los coranes en árabe que existieron en la época en la península ibérica y sus distintas divisiones y lecturas (López-Morillas, 2012; Chiru, 2013 y 2015). Este impulso en el estudio de los coranes moriscos como textos traducidos por musulmanes en circunstancias complicadas (Arias, 2007, 2016 y 2020) ha abierto nuevas perspectivas en la comprensión de los textos religiosos aljamiados. Especialmente el Corán completo contenido en el manuscrito T12 de la Biblioteca de Castilla-La Mancha en Toledo, escrito en caracteres latinos, ofrece todavía muchas posibilidades de estudio acerca del trasvase al castellano desde su original árabe (López-Morillas, 2011; Arias, 2016).

\section{TRADUCCIONES QUE ABREN ESTE MUN- DO. ROMANCEADORES Y TRADUCTORES OFICIALES}

Los mudéjares y moriscos granadinos no necesitaban traducciones para su vida islámica porque, como decía Ignacio de las Casas, ellos eran cabeza de los musulmanes en España por seguir usando el árabe. Eran los cristianos quienes debían aproximarse a su lengua, primero, para coexistir con ellos en el reino conquistado a finales del siglo Xv; segundo, para mantener las estructuras sociales y fiscales que, heredadas de época nazarí, bien servían a las nuevas autoridades castellanas, y, tercero, para poder tener alguna esperanza de una conversión al cristianismo efectiva y sincera de los moriscos arabohablan- tes. El árabe se insertaba además con la subida al poder del rey Carlos en un imperio multilingüe en el cual la administración debía mantener correspondencia tanto con otros Estados como con diversos territorios con diferentes lenguas bajo su dominio. De esta forma, como complemento de la fundación en 1527 del Consejo de Estado por parte del emperador, el mismo año se crea la Secretaría de Interpretación de Lenguas para acometer la tarea de traducir correspondencia y documentación oficial. El primer Secretario de Interpretación oficial fue el humanista Gracián de Alderete, aunque al parecer antes esas funciones fueron desempeñadas de forma oficiosa por el traductor de árabe Gómez Díaz de Arabia y el secretario Alonso de Valdés como traductor de latín (Cáceres, 2004b: 611). La Secretaría de Interpretación de Lenguas fue poco a poco dedicándose esencialmente tanto a los documentos en latín como a los escritos en lenguas europeas, quedando los documentos árabes, persas o turcos que interesaban a la administración en manos de traductores individuales que, aunque contratados por el Estado, no pertenecían orgánicamente a la Secretaría.

Si bien la lengua se va a convertir pronto en uno de los grandes caballos de batalla del dominio efectivo de Granada y de sus mudéjares y después moriscos, el hecho era que, como ha subrayado Ángel Galán, los dominadores necesitaban tocar lo menos posible los sistemas de gestión fiscal y de gestión de territorios que habían pervivido de la época nazarí (Galán, 2016). La labor de intermediación social y cultural de los intérpretes que durante siglos se había llevado a cabo con los mudéjares castellanos o de la corona de Aragón ahora debía focalizarse en el reino de Granada (Salicrú, 2005). Igualmente, los intérpretes y traductores de los que se servía la Inquisición en otras zonas (Labarta, 1982; Sarmiento, 2015 y 2016) —de los que no sabemos 
demasiado- pasaban a ser activos igualmente en Granada. No solamente los actos de los reyes, nobles o concejos, sino también los contratos entre particulares en Granada, por no hablar de recaudaciones que precisaban de padrones, deslindes de tierras, títulos de propiedad o límites de posesiones, entre otras actuaciones, quedaban después de la conquista sometidos a un sistema de expresión bilingüe. Mientras que los primeros solían requerir la asistencia de un intérprete o escribano oficial, los contratos entre personas privadas, o entre estas y las instituciones locales solían ser traducidos y/o interpretados por moriscos bilingües. Estos moriscos servían de puente entre la Corona y sus representantes y los miembros de las oligarquías moriscas del reino de Granada, en buena parte monolingües.

Las figuras de intérpretes, lenguas, romanceadores y escribanos van a llenar buena parte del siglo XVI, especialmente en Granada, como muestra tanto de la plena vida del árabe como del interés de las autoridades cristianoviejas en dar valor legal a lo escrito en esa lengua. La enorme presencia de los intérpretes y su profunda huella ha recibido una atención especial en los últimos tiempos, destacando los trabajos de Mercedes Abad sobre la actuación de los intérpretes profesionales $\mathrm{u}$ ocasionales en la parte oriental del antiguo reino de Granada (Abad, 2005a, 2005b, 2008 y 2011). El intérprete, cuya figura está ya regulada en las ordenanzas de Granada de 1500 (García Pedraza, 2002: 470), tiene una actividad tan variada que, como ha mostrado Abad (2008), a través de sus actividades podemos analizar fenómenos como el intervencionismo en las traducciones, la honestidad (o carencia de ella) en sus traducciones, los intérpretes espontáneos, los anónimos, los intérpretes parciales en favor de quien les paga, intérpretes a su vez interpretados, foráneos y mudéjares de Aragón como intérpretes, etc. Se trata de un mundo de negociación cultural y política en el que los intérpretes ocupan el centro de la escena, desempeñando un rol cada vez más importante y variado, con consecuencias legales y sociales derivadas de su trabajo.

Mientras que los intérpretes representan la dimensión oral de la traducción, por más que en muchos casos se mezclen con testimonios escritos, los romanceadores son la personificación de la dimensión escrita de la misma. Puesto que su actividad suele generar documentación con validez legal, y su traducción ha de ser por tanto fehaciente (Abad, 2011), su designación como tal es siempre oficial y cobra por su actividad profesional de los concejos o de la corona, por lo que su nivel social y profesional, a diferencia del intérprete, suele ser alto. A veces combinan sus cargos con el de escribano público de su Majestad, con lo que su naturaleza de fedatarios se dobla. En ocasiones, además, podemos comprobar que algunas familias generan casi dinastías de traductores, como los Xarafi granadinos (Feria y Arias, 2005), cuyos puestos suelen ser bastante ambicionados. Igualmente, algunas familias judías, como los Sasporta o los Cansinos en Orán, o los Pallache en Marruecos, combinaron sus labores mercantiles con su actividad de traductores casi vitalicios en el campo diplomático (Schaub, 1998; García-Arenal y Wiegers, 1999). Los textos romanceados del reino de Granada que se conservan, algo más de doscientos, editados casi todos, aunque con desigual fortuna, son un auténtico venero para poder estudiar los fenómenos de traducción árabe-castellano en la Granada del siglo XVI. Sin embargo, esta «mina a cielo abierto» para los estudios traductológicos, como han sido recientemente calificados (Arias y Feria, 2004), solo muy recientemente han recibido atención especializada en tal sentido, por más que algunos de sus editores ya vislumbra- 
140 ron sus posibilidades de estudio desde el ámbito de la traducción. Los perfiles sociológicos de los traductores, su pericia traductora, los ámbitos de sus actuaciones, su posible especialización, la forma de traducción de diversas clases de términos, los encargos de traducción, etc., son elementos que han de ser estudiados para todas estas figuras que actuaron principalmente en Granada, pero cuya actuación abarcó toda la Península (Feria, 2001a: 145-227).

Algunos de estos romanceadores, que nunca fueron numerosos, fueron de designación real y solían ocuparse de los papeles árabes que generaba la diplomacia y, en general, la política de los Austria, de naturaleza extensamente multilingüe. Tanto los documentos árabes que llegaban por un motivo $\mathrm{u}$ otro a la corte, como encargos extraordinarios como la catalogación de los libros árabes de Muley Zaydán, que habían llegado a la biblioteca de El Escorial en 1621, la catalogación de los textos epigráficos de la Alhambra o la intervención como agentes de propaganda en la Guerra de las Alpujarras, hechos los dos últimos protagonizados por Alonso del Castillo (Castillo, 1852) podían formar parte del trabajo de los romanceadores oficiales del rey. Varios de estos romanceadores fueron de origen y familia moriscos, como Alonso de Venegas y su estirpe, el propio Alonso del Castillo o Miguel de Luna, lo que en algunas ocasiones acarreó ciertos problemas en torno a su credibilidad como traductores. Pero también los hubo cristianos viejos, como quizá lo fuera Juan Rodríguez y sus hijos y ya en el siglo XVII el vasco Francisco Gurmendi, quien tradujo del árabe para el rey dos tratados del género de espejo de príncipes que aún se conservan inéditos (Llopis, 2016). Aunque los dos traductores moriscos han recibido hasta ahora una cierta atención crítica por sus especiales perfiles y por su intervención en el asunto de los libros plúmbeos del Sacromonte, pública como traductores y quizá secreta como ideadores (Cabanelas, 1965), los otros romanceadores, algunos de obra extensa, merecen igualmente un nuevo acercamiento crítico. Una de las figuras más atractivas como traductor que apareció en la España del siglo XVI, el napolitano capturado y criado entre musulmanes Diego de Urrea ha sido estudiado por Fernando Rodríguez Mediano y Mercedes García-Arenal que han estudiado en él la confluencia de varios de los vectores relacionados con la lengua árabe y la monarquía española en el siglo xvI: el árabe como factor de cultura e historia, su enseñanza en la universidad, su uso político y su utilidad para destapar supercherías (García-Arenal y Rodríguez Mediano, 2002 y 2010). No en vano fue de los pocos que vio negro sobre blanco cómo en el asunto del Sacromonte las únicas traducciones posibles eran las que esperaba el obispo Pedro de Castro (Floristán, 2013: 230-231). Otro de estos extranjeros que se hicieron hueco como traductores del árabe en España fue el kurdo Marcos Dobelio, cristiano oriental asentado en Roma, donde daba clases en la Sapienza, y que acudió a España al calor de los libros del Sacromonte y que prestará servicios de traducción a las autoridades españolas (García-Arenal y Rodríguez Mediano, 2010: 251-307). Unos análisis y valoración críticos de las traducciones del árabe, del persa o del turco de estos hombres que marcaron los traslados cultos de las «lenguas orientales» en el siglo XVI y comienzos del siglo XVII aún deben ofrecer muchos e interesantes resultados. No en vano posiblemente debemos a las traducciones de Alonso del Castillo de las epigrafías de la Alhambra el que las inscripciones de tipo religioso islámico, sospechosamente ausentes de su manuscrito, hayan llegado hasta nosotros (Rubiera, 1995: 98-99). 


\section{TRADUCCIONES QUE ABREN OTROS MUNDOS. LA EVANGELIZACIÓN DE LOS MORISCOS}

La voluntad de ocupación y dominio por parte de los cristianos de las estructuras económicas y sociales que habían perdurado desde la época nazarí propició, como se ha visto, la proliferación de romanceamientos y romanceadores que pudieran acometer la realidad lingüística del reino de Granada. Esa realidad de la casi exclusiva existencia del árabe, que nadie discutía desde el momento de la conquista y que no parecía plantear problemas de concepción en las primeras décadas del siglo XVI, se va a ver, sin embargo, paulatinamente amenazada conforme se va ejerciendo presión sobre la lengua árabe al ser identificada por las autoridades, primero religiosas, luego políticas, como fundamental elemento de identidad islámica (Abad, 1997). Aunque ese carácter identitario será un argumento discutido por varias personalidades como Francisco Núñez Muley o Ignacio de las Casas, el hecho es que ya desde 1511 el árabe ha sido puesto en la casilla de las «diferencias» moriscas a ser eliminadas. Especialmente en las medidas de aculturación morisca aprobadas en la Congregación habida en la Capilla Real a instancias del rey Carlos en 1525, la interdicción del árabe aparecía por primera vez de forma oficial (Gallego y Gámir, 1996: 202)

por obviar y remediar los daños e inconvenientes que se siguen de continuar los dichos nuevamente convertidos a hablar arábigo, mandamos que ninguno de ellos, ni sus hijos, ni otra persona alguna de ellos, no hable de aquí adelante en arábigo, ni se haga escritura alguna en arábigo, y hablen todos la lengua castellana.

Esta misma presión se ejercerá contra los moriscos de la Corona de Aragón, especialmente los valencianos, aunque allí nunca se llegará a 141 generar una prohibición tajante sobre la lengua. Como es conocido, las medidas se irán aplazando a cambio de aportaciones monetarias, hasta su entrada definitiva en vigor en 1566, con Felipe II.

La discusión acerca de si el árabe es o no una lengua que se identifica con el islam y viceversa apareció en varias ocasiones a lo largo del siglo XVI, especialmente por parte de aquellos que se oponían a las medidas oficiales y señalaban a los cristianos de oriente como ejemplos de creyentes que hablaban árabe. Igualmente, García-Arenal y Rodríguez Mediano han mostrado en un magnífico libro (García-Arenal y Rodríguez Mediano, 2010) cómo abundaron las discusiones sobre el árabe como una de las lenguas antiguas de la humanidad (y de España) y su importancia para escribir su historia, incidiendo además en la dicotomía árabe dialectal/ árabe clásico como lo propio de moriscos, por un lado, y lo propio - e inocente-de eruditos. De esta forma puede explicarse esta paradoja de una triple realidad de la lengua árabe en la primera mitad del siglo XVI en España: por un lado, la lengua de la realidad granadina y valenciana, esencial para la comunicación diaria y que hay que conocer y trasladar al castellano; por otro lado, la lengua de la erudición y la historia, que ayuda a conocer los orígenes de España; y, finalmente, la lengua propia de los musulmanes en la península, la que conlleva dentro de sí la carga de pertinacia en seguir firmes en la creencia del islam. Depende mucho de en qué contexto nos encontremos para poder inclinar la balanza a un lado o a otro: lo que para la mayoría es lengua del islam, para otros es lengua antigua o simplemente propia de los naturales de la tierra, como sostenía Núñez Muley (Gallego y Gámir, 1996); lo que unos toman por huellas de fe, para otros son rastros heredados y legítimos de un pasado. Seguramente ninguna posibilidad elimina a la 
142 otra y son factores externos los que periódicamente hacen que la opinión mayoritaria se incline por una u otra.

La evangelización de los musulmanes a partir de la conquista de Granada es precisamente uno de esos campos en los que se puede ver esa confluencia de distintas visiones. Aunque, hay que recordar, el árabe no aparecía como hecho problemático desde las capitulaciones, muy pronto se va a ver su existencia como hecho diferencial que impide la inserción de los moriscos en la sociedad de cristianos viejos. El propio arzobispo Hernando de Talavera, quien tanto pugnó por integrar el árabe en su labor evangelizadora a través de su propio ejemplo y del patrocinio de los trabajos de Pedro de Alcalá, veía claro que el mantenimiento público de la lengua era un obstáculo para una integración plena (Azcona, 1964: 762-763):

Que los que sabéis leer, tengáis todos libros en arábigo de las oraciones y salmos que vos serán dados, y de aqueste memorial, y recéis por ellos en la iglesia. [...] Mas para que vuestra conversación sea sin escándalo a los cristianos de nación y no piensen que aún tenéis la seta de Mahoma en el corazón, es menester que vos conforméis en todo y por todo a la buena y modesta conversación de los güenos y honrados cristianos y cristianas, [...] y mucho y más que mucho en vuestro hablar, olvidando cuanto pudiéredes la lengua arábiga, y haciéndola olvidar, y que nunca se hable en vuestras casas.

El breve texto de Talavera es muy elocuente de la doble naturaleza del árabe tal y como es visto por los evangelizadores llegados a Granada. Como lengua que puede verter los conceptos cristianos es válida y útil, pero en boca de los nativos de Granada es personificación del islam, por lo que estos deben ir abandonándola progresivamente. Esta visión es la que explica la coexistencia de una política de búsqueda de clérigos capaces en árabe y de enseñanza de la lengua con el progresivo acoso a sus hablantes naturales. Como es conocido, el patrocinio de Talavera amparará las obras de Pedro de Alcalá, el Arte para ligeramente saber la lengua arábiga, la más antigua gramática misionera occidental, y el Vocabulista arábigo en letra castellana, el diccionario para misión más antiguo existente (Zwartjes, 2014) aparecidas en 1505, pero posiblemente compuestas hacia 1499. Frecuentemente reimpresos juntos, el primero incluye contenido doctrinal (oraciones, ritual, exposición práctica de la relación sacerdote-fiel) expuesto en árabe, castellano-árabe o latín-árabe que ha sido estudiado desde el punto de vista de su estrategia de presentación del cristianismo a los moriscos granadinos (Ricard, 1928), eligiendo términos árabes para las realidades cristianas o importando términos castellanos en el árabe granadino para ciertas nociones. Ha sido menos estudiado, sin embargo, desde el punto de vista de su adaptación de la religión a través de la traducción de textos prexistentes: la parte que incluye las fórmulas de las misas, por ejemplo, son traducciones de los misales de la época (Folgado, 2015) que aún deben ser analizadas. Alcalá era muy consciente tanto del diálogo que el cristianismo debía mantener con las realidades culturales de los moriscos - como se ve en su insistencia de que es Dios, y no el sacerdote, quien perdona realmente los pecados-, como de las distintas realidades que castellano y árabe pueden dibujar en un diálogo como la confesión (Pezzi, 1987):

Cada una de las lenguas tiene su manera de hablar y con aquélla se deve el hombre cuerdo conformar, quanto buenamente pudiere, porque de otra manera más sería enfuscar que interpretar lo que onbre quisiere dezir. E por esso en el presente interrogatorio muchas de las preguntas van asi al pie de la letra sacadas parte por parte en el aravia porque lo sufrio la lengua, y otras no asi porque no 
lo sufrio la lengua, mas solamente la misma sentencia aun que por otros términos. Y lo presente sea dicho por aquellos que son inclinados a reprehender y no a defender las obras de los prójimos (Arte: ff. 27-27v.).

La confesión fue uno de los núcleos importantes de la reflexión acerca de cómo acercar los sacramentos a los moriscos que hablaban árabe, y fue tratada por todos los catecismos bilingües con un enfoque similar, aunque con matices diferentes. Los distintos métodos para asegurar la comunicación entre confesor y confesante suponían un esfuerzo por integrar el árabe en la enseñanza cristiana, pero igualmente un método de mayor control del pensamiento, instrucción y comportamiento de los moriscos (Gilbert, 2018).

A este esfuerzo de Hernando de Talavera se iba a sumar en 1501 el confesor personal de la reina Isabel y predicador real Martín García Puyazuelo, cuya fama en Aragón ya era notable. Sus cualidades como conocedor del judaísmo y el islam, así como del árabe y el hebreo, le hacían para la reina persona especialmente adecuada para la misión y así le conminó a acudir a Granada:

Maestre Martín García, ya sabeys como todos los moros de la ciudad de Granada se convirtieron a nuestra santa fe catholica; porque muy pocos dellos saben entender hablar sino arabigo y por no haver personas de iglesia que sepan el arabigo, no pueden los dichos convertidos ser bien instruidos en las cosas de nuestra fe y ay mucha necesidad especialmente agora en los comienzos que no hay en aquella ciudad personas de iglesia que sepan arabigo para instruir a los dichos nuevamente convertidos y porque sabemos que vos sabeys arabigo y que con vuestras letras y predicación y buen ejemplo podreys muchos aprovecharles (Montoza, 2018: XVII).

Martín García añadía a la predicación evangélica una capacidad de polémica religiosa an- tiislámica de la que ya había dado muestra en Aragón (Soto y Starczewska, 2016). En Granada va a colaborar con Juan Andrés, mudéjar de Xàtiva convertido al cristianismo, antiguo alfaquí o, al menos, con profundos conocimientos del islam, que va a escribir una de las obras clave del siglo XVI, la Confusión o confutación de la secta mahomética y del Alcorán (Valencia, 1515), en la cual transcribe, traduce y comenta numerosas citas del Corán y de la sunna. La obra de Juan Andrés va a conocer un notable éxito editorial tanto en España, con numerosas reediciones, como en Europa, con traducciones al italiano, latín, inglés, alemán y neerlandés. Su influencia será más que palpable en los antialcoranes posteriores (Szpiech, 2012). Del mismo modo, la influencia y método de Martín García se va a extender igualmente a quien le sustituyó como predicador en la Seo de Zaragoza, Juan Martín Figuerola, quien compondrá una extensa Lumbre de fe contra el Alcorán (1518-1521) que incluye asimismo pasajes del Corán escritos en árabe, transcritos y traducidos al castellano. Figuerola tiene la particularidad de colaborar con un antiguo alfaquí convertido de Teruel, Juan Gabriel, quien actuó como su maestro de lengua y religión y que se identifica con el Ioannes Gabriel Terrolensis que realizó la traducción latina del Corán encargada por el cardenal Egidio de Viterbo en 1518, que contenía también el texto original árabe y una transcripción en caracteres latinos (García-Arenal y Starczewska, 2014). Herederos indirectos de Martín García y de Juan Andrés serán Bernardo Pérez de Chinchón en Valencia y Lope Obregón en Castilla, quienes igualmente dirigirán su predicación a los moriscos a través de la traducción y la polémica religiosa.

Dentro también de esta línea de aprendizaje y uso del árabe como elemento fundamental para la predicación entre moriscos es importante la figura de Martín Pérez de Ayala, especialmente 
144 a partir de su experiencia directa con los moriscos durante su obispado en Guadix (1548-1560). Para su acción siempre buscará clérigos que pudieran predicar en árabe a los nuevos cristianos, aunque su éxito en tal sentido no será grande debido a no poder contar con sacerdotes moriscos. Ya en las actas del Sínodo de Guadix (1554) publicará un breve catecismo para cristianos nuevos que será traducido al árabe por Bartolomé Dorador, uno de esos cristianos viejos que sabían árabe de los que tan poco conocemos (Torres, 1971). El ejemplar en árabe granadino, del que se ha desgajado el original castellano, se conserva en la Biblioteca Nacional de Argel y no ha recibido demasiada atención, reclamando un estudio de sus técnicas de traducción para trasvasar la doctrina cristiana. Mucho más conocida es su Doctrina Christiana en lengua arábiga y castellana compuesta e impresa por mandato del Ilustrísimo y Reverendísimo Señor D. Martín Pérez de Ayala, publicada muy poco después de su muerte en 1566 en Valencia, de cuya sede había sido arzobispo. Más de treinta años después de su muerte, en 1599, y por intervención de Juan de Ribera, se publicará en Valencia a partir de lo hallado entre los papeles de Ayala un Catechismo para instrucción de los nuevamente convertidos de moros. Impresso por orden del Patriarcha de Antiochia y Arçobispo de Valencia Don Juan de Ribera, estructurado en forma de diálogo en castellano entre un maestro y un discípulo musulmán que desea formarse en el cristianismo.

La Doctrina Christiana, que presenta sus materiales de forma sencilla en castellano con traducción interlineal en árabe transcrito, sí que ha recibido algo más de atención desde que Julián Ribera escribiera un prólogo a la edición de 1911 criticando el método escogido por el obispo Ayala para enseñar el cristianismo a los moriscos (Pérez de Ayala, 1911 [1566], VI-VII):
[...] la obra cuya publicación con tanto celo apostólico patrocinó el arzobispo de Valencia para el provecho espiritual de los conversos, no podía servir sino para diversión y burla de los nuevos cristianos. Si los sesudos misioneros enviados por el arzobispo para instruir á los conversos, leían en el púlpito aquellas oraciones en árabe, ¿qué risa no provocarían en el pueblo morisco, cristiano en apariencia y musulmán recalcitrante en el fuero interno? [...] El sistema de traducción adoptado para formar la doctrina [...], fué el siguiente:

«poner cada dicción arábiga debajo de la castellana á quien responde», es decir, que se hizo calcando mecánica y nimiamente las frases. El que tenga un poquitillo de experiencia en tales materias, comprenderá que el método es infantil; los vocablos sueltos serán árabes, pero la frase resultará disparatada é ininteligible.

Este duro juicio ha recibido varias matizaciones y objeciones desde el punto de vista de la traducción, señalando que quizá se está ante un primer esfuerzo por separarse de las estructuras latinas como expresiones reverentes (Peña y Vega, 2001), o bien que esa opinión de Ribera no tiene en cuenta ni que la pauta de traducción viene determinada por una jerarquía de lenguas encabezada por el castellano ni se cuestiona si la voz que se expresa en árabe busca, más que una traducción fidedigna, una aproximación lingüística negociada y con términos familiares a la cultura de los moriscos granadinos arabehablantes (Carbonell, 1999: 239-243). Al presentar la fórmula para hacer la señal de la cruz, por ejemplo, la Doctrina indica: «En el nombre del padre / Biçmiléhi huíld, y del hijo, y del Spiritu Sancto, / hueled roh alcúduç / un Dios. Amen / huáhed Allah. Amín.» (Pérez de Ayala, 1911 [1566]: f. 8r-v), siguiendo en esto a Hernando de Talavera y adaptando en cierto modo la formulación de la trinidad al rotundo monoteísmo islámico (Resines, 1994). 
Las últimas opiniones expresadas indican una vía de análisis de las versiones del cristianismo traducidas al árabe que debe ser explotada en profundidad. Inculturación, adaptación, interpretación, literalidad, etc. son términos que se han utilizado para caracterizar estas traducciones de la doctrina y el ritual cristianos dirigidas a los moriscos granadinos. Estos tenían — no ha de olvidarse - un cierto conocimiento del cristianismo y de los puntos polémicos entre este y el islam, por lo que las traducciones árabes a ellos destinadas debían contar con esa realidad para pretender ser efectivas. Para los moriscos algunos de los conceptos que se manejaban en el ritual cristiano eran como tal sencillamente inconcebibles, por lo que eran necesarias prevención y reflexión por parte de los sacerdotes a la hora de presentarlas traducidas. Hay que tener en cuenta, además, que en ciertos sacramentos como la confesión se producía una conversación directa entre religioso y morisco que podía complicar todavía más la intelección de vocablos, aunque se recurriera, como sucedía con otras lenguas, a un intérprete, como advertía Ignacio de las Casas:

¿Cómo a de saber dezir el intérprete que sólo sabe esta lengua conforme a la secta de Mahoma y no es docto en nuestras letras antes es necessario para entenderlo él otro intérprete que se lo declare quando a de dezir Trinidad, personas divinas, divina esencia, unión hipostática Dios y hombre, sacramentos, missa, comulgar y confessar, absolver y otros términos sin número que para los moros en su secta son tan inauditos como entre nosotros los de su Alcorán y ceremonias? (Sarmiento, 2018: 12).
4. LA TRADUCCIÓN DESDE LA OTRA ORI-

\section{LLA. LOS LIBROS PLÚMBEOS DEL SACRO-} MONTE

Que los musulmanes en la península ibérica sabían más de cristianismo que los cristianos de islam después de varios siglos de contactos era algo que sabían bien los moriscos que urdieron y pusieron en escena el fantástico asunto de los libros plúmbeos del Sacromonte de Granada. Esas láminas de plomo escritas en árabe que fueron halladas en el monte Valparaíso de Granada en la última parte del siglo Xvi planteaban la difícil paradoja de colocar al árabe para testimoniar los orígenes cristianos de Granada y España. Aunque solo fuera por el simple hecho de tener integrado al cristianismo dentro de su visión histórica de las religiones de la humanidad, que culmina en la revelación del islam, los musulmanes tenían - y tienen — claro cómo fue el cristianismo primigenio y cómo se pervirtió por la inclusión en él de creencias forjadas por humanos. Revelar un verdadero mensaje cristiano primitivo y clandestino implicaba sobre todo habilidad para esconderlo física y conceptualmente. Lo primero se logró fácilmente en una época de maravillosos hallazgos sacros; lo segundo se hizo amparándose en ese papel del árabe como lengua antigua de la historia que se estaba debatiendo desde tiempo atrás. Una vez hallados los textos y autenticadas las cenizas y reliquias, había que alcanzar el mensaje de los maravillosos textos traduciéndolos. Probablemente en pocos momentos de la historia de España la traducción del árabe jugó un papel teórico y práctico tan fundamental como en todo el asunto que tuvo en vilo a intelectuales y eclesiásticos durante muchos años.

Se conoce bien el proceso mediante el cual el obispo Pedro de Castro fue reclamando traductores que pudieran ofrecer una adecuada tra- 
146 ducción de los textos. No tantos eran capaces de hacer esto en España a finales del siglo XVI, y buena parte de los que podían se vieron involucrados, de una u otra forma, en la traducción de los libros plúmbeos. Conforme a lo que era ya acostumbrado, estaban escritos en una lengua extraña que necesitaba de un traductor avezado para dar buena cuenta de sus contenidos.

Los «caracteres salomónicos» en los que se decían escritos los plomos fueron pronto destapados: las grafías correspondían, con modificaciones en la escritura, al alifato árabe. Éste, sin embargo, no solo estaba desprovisto de vocales como es usual en árabe, sino que carecía asimismo de parte de los puntos diacríticos que distinguen una consonante de otra. El hecho ponía en prevención a los posibles traductores: las palabras podían ser interpretadas de formas distintas según lo que se leyera. Así lo señalaba el gran Arias Montano (Godoy Alcántara, 1981 [1868]: 85-86):

El pergamino [...] no lo leerán cuatro que entiendan la lengua, sin variar en muy muchos lugares en grande manera, porque no solamente carece de güelas o haracas, que son las vocales (que esto no hace mucho negocio a quien está diestro en leer), sino, lo que más importa, está falto de los puntos sustanciales de las letras consonantes; y por esto juzgo yo que hará adivinar a los ingenios, porque una misma figura de letra con un punto dice una cosa, y con otro u otros otra, y puestos debajo tienen diversa fuerza que encima, y por consiguiente diversa significación; y así conviene tratar dél como de cifra varia [...] y si los nueve libros están escritos en la misma forma darán bien que hacer a diversos intérpretes.

Por otra parte, no valía de nada que algunos críticos invocaran la modernidad del lenguaje de los textos, con giros propios de los moriscos en España: gentes diestras en árabe y de confianza del arzobispo Castro, los intérpretes moriscos Alonso del Castillo y Miguel de Luna, habían jurado la antigüedad y solemnidad de la lengua árabe de los plomos (Cabanelas, 1965: 281).

En este caso, la lengua árabe de los textos juega un papel distinto del caso de la evangelización. Presentados como textos cristianos y siendo el árabe una de las lenguas de la antigüedad, el árabe actúa aquí como depositario de una verdad evangélica y granadina. Salvado el obstáculo de considerarlos textos islámicos por la lengua, se hace imprescindible conseguir unas traducciones que respondan a esa naturaleza. Con la expectación creciendo sin parar, se llevan a cabo las primeras traducciones a cargo de Luna y Castillo. A principios de marzo de 1597, menos de dos años después de los primeros descubrimientos, Pedro de Castro reúne una junta de teólogos para que diera su parecer sobre el contenido de los libros. El parecer es rotundo y unánime (Valencia, 1999: 261-262):

[...] y nos pareze y dezimos, todos unánimes y conformes, que contienen los dichos libros Santa Católica y Apostólica doctrina: Teología altísima, positiua y escolástica [...] sobrenatural y reuelada, que excede las fuerzas y lumbres del entendimiento humano, y que parece dictada por el Espíritu Santo. No contrauienen en cosa alguna a las Sagradas Letras, determinaciones de Concilios, ni a la doctrina común de los santos, ni en lo que tienen de Historia no hay en ella cosa sospechosa [...] y declaran cosa en grande honra y gloria de Dios y consuelo del mundo y de la Iglesia Católica: estirpan y confunden toda la morisma, y paganismo, todos los herejes y herejías presentes [...] y están en lengua que no pueden decir los hereges, que los ha compuesto nadie en este tiempo y parece prouidencia de Dios auer guardado tantos siglos y reuelarlos en este tiempo, para el remedio de los dichos daños [...]. 
Los teólogos reunidos en Granada estaban seguros de que los plomos eran textos cristianos escondidos por Dios, pese a que ninguno tenía idea de árabe. O probablemente por eso. Cualquier juicio eclesiástico sobre los plomos va a depender de intérpretes y juicios externos. Desde el primer momento, la opinión sobre la naturaleza doctrinal de los textos se obtiene no de ellos, sino de las traducciones que se van efectuando. Una vez que las primeras traducciones han confirmado la naturaleza cristiana de las láminas en árabe, éstas irán siendo analizadas según esta pauta. Son las traducciones las que van caracterizando a los textos, no a la inversa.

Toda la actuación de Castro buscando continuamente intérpretes de árabe (Harvey y Wiegers, 1996; García-Arenal y Rodríguez Mediano, 2002) para interpretar los textos estaba viciada por este a priori. Pedro de Castro no buscaba una traducción fiel en el sentido que hoy puede tener el adjetivo; lo que buscaba era una traducción que se ajustase a lo que él creía que contenían los plúmbeos. Cuando alguien criticaba las traducciones que habían salido del ámbito de Castro, el arzobispo se enfurecía dudando de la competencia lingüística del enemigo, al atreverse a discutir la para él obvia naturaleza cristiana de los textos (Bernabé Pons, 2009: 482):

Y no es para esto necessario saber la lengua Arabe [...] No conuiene, ni tiene el libro de Essentia Dei [...] ni ningún otro libro, nada de la secta de Mahoma: antes lo contrario: todo la destruye [...] es doctrina de Christo [...].

Es lógico entonces que las traducciones sufragadas por Castro fueran modelando una lectura católica de los textos árabes. Cualquier otra posibilidad no solo era impensable, sino que Pedro de Castro la combatiría con acritud, como bien supieron el jesuita morisco Ignacio de las Casas o el traductor real Francisco Gurmendi. Asílo se- ñala Ignacio de las Casas al hablar de las traducciones realizadas por los traductores moriscos (Benítez Sánchez-Blanco, 2002):

\begin{abstract}
[...] supe por cosa cierta que quando interpretavan, que era siempre en presencia del Arzobispo o de otros por él, les decían quando topaban dificultades: «iNo pueden decir así! ¿No dirá así?». Con lo qual les impedían decir la verdad, más siendo ellos descendientes de los árabes y temerosos de no ser tenidos por hombres que decían contra la Fee, como dijeron ellos propios.
\end{abstract}

Eran, naturalmente, traducciones interesadas en el sentido de complacer al obispo confirmando el mensaje que él veía en los plúmbeos. Lógicamente, las versiones castellanas comenzaron a incluir terminología y nociones cristianas que no aparecían en los textos, sino que surgían de una interpretación de ellos. Traducir el sintagma de los plúmbeos «Yasū " rūh Allāh» «Jesús espíritu de Dios» por «Hijo Encarnado de Dios», como hace, por ejemplo, la versión del marqués de Estepa, es afirmar en la traducción este carácter cristiano de los libros plúmbeos. Se trata de un proceso de traducciones y versiones en castellano y latín que se conserva en numerosos manuscritos especialmente en la Abadía del Sacromonte y en la Biblioteca Nacional de Madrid y cuyo estudio y análisis no ha sido emprendido. Contando solamente en la actualidad publicadas la traducción procristiana del marqués de Estepa (Hagerty, 1980) y la muy reciente y aún parcial de van Koningsveld y Wiegers (2019), sería muy deseable poder estudiar cómo a través de unas traducciones se va generando una interpretación particular de unos textos. Hoy sabemos que algunos moriscos que tuvieron acceso a los plomos los interpretaban como textos islámicos, pero ellos no tenían que depender de las traducciones. 
148 La mayoría de los investigadores están de acuerdo en la factura morisca de los plomos, aunque haya divergencias en cuanto a su propósito. Algunos de esos moriscos, como el granadino Miguel de Luna, sabía que llegaría pronto su turno para traducir los textos árabes y dar su versión, cristiana y coincidente con la de Castro. Hoy sabemos que dentro de su comunidad pensaba otra cosa (García-Arenal, 2010b), pero sus traducciones se dirigían a la Granada oficial y cristiana. A los moriscos de allí les bastaba con los textos en árabe, que podían leer e interpretar. Respecto a lo demás, solo le podían acusar de hacer malas traducciones.

\section{TRADUCCIONES SIN TRADUCTOR. MUN- DOS POSIBLES}

Cide Hamete Benengeli es, naturalmente, uno de los más conocidos historiadores arábigos gracias a un - de nuevo - anónimo traductor, un morisco aljamiado de Toledo que se prestó a traducir la crónica que Miguel de Cervantes había puesto en sus manos. Gracias a su pericia lingüística, las aventuras del famoso caballero Don Quijote de la Mancha comenzaron a excitar el oído del escritor de Alcalá. Por supuesto, siendo el propio Cide Hamete un morisco, él mismo podría haber escrito su relato en castellano, o podría haberlo traducido sin ayuda. Pero nos hubiéramos quedado sin un delicioso juego metaficcional que tiene uno de sus resortes en la traducción de un manuscrito árabe que por ahí andaba. Cervantes usaba algunos de los artificios literarios más conocidos de la España de comienzos del XVII para crear el manuscrito «original» del Quijote: en primer lugar, claro, el manuscrito oculto (Hagedorn, 2006); en segundo lugar, la necesidad de un traductor avezado; en tercero, la fabulosa historia que el manuscrito contenía y que se conoce gracias al acto de traducción.
Modelos no le faltaban a Cervantes en la España del XVI (García-Arenal y Rodríguez Mediano, 2010: 203-205) y, desde luego, los moriscos eran uno de los más evidentes, en especial con el asunto del Sacromonte como lugar de ocultación y descubrimiento por antonomasia. Pero importa señalar antes el hecho de la factualidad del árabe como aproximación de la historia de Cide Hamete Benengeli a un contexto más «real» frente a fabulosos manuscritos griegos o hallados en exóticas bibliotecas monásticas. La asunción de este juego es que una historia antigua narrada en árabe tiene más visos de ser española que no una en griego. El árabe, que como se ha indicado era considerada una de las primeras lenguas presentes en la península ibérica (García Arenal y Rodríguez Mediano, 2010), conectaba los textos con un venero narrativo europeo que pertenecía en exclusiva a España. Lo fundamental, además, no eran los propios textos en árabe, que pocos en España podían juzgar con autoridad, sino las traducciones, que en la práctica se convertían en los textos reales.

En este sentido es completamente lógico que algunos de los más exitosos libros en España eran los que, tratando de historia árabe o morisca, se presentaban como traducción de antiguos manuscritos árabes. Ginés Pérez de Hita en su Historia de los vandos de los Zegríes y Abencerrajes, cavalleros moros de Granada (1595) acude al testimonio del moro Aben Hamin, testigo de los hechos narrados y recopilador de papeles y noticias (Pérez de Hita, 1595: 24):

[...] assí como la escriuió el Moro Abenhamin, historiador de todos aquellos tiempos, dende la entrada de los Moros en España: porque este Abenhamin tuvo muy solícito cuydado de recoger todos los papeles y escrituras que tratauan estas cosas de Granada. 
Igualmente, Miguel de Luna, el médico morisco y traductor de árabe, también sacó a la luz una «historia» que halló en un manuscrito árabe de la Biblioteca del Escorial. La Historia verdadera del rey don Rodrigo cuenta la historia de la conquista de España por parte de los árabes, narrada igualmente por un testigo directo, Abulcaçim Abentarique (Luna, 2001 [1592]). La visión de Miguel de Luna de la España visigoda conquistada por los musulmanes es radicalmente distinta de las historias tradicionales, con un gobierno árabe pacífico y hacendoso frente a los traicioneros visigodos. Luna extiende su trabajo oficial de traductor para conducirnos por los pliegues de la ficción/realidad, anotando cuidadosamente al margen de su texto cuestiones terminológicas y dudas para dejar sin cuestión a quien se plantee la naturaleza de su obra, muy exitosa, por cierto.

Miguel de Luna, pese a sus continuas quejas acerca de su situación social y económica, siempre gozó de la confianza de gente poderosa. Fue en especial cercano al arzobispo de Granada Pedro de Castro con sus traducciones de los libros plúmbeos del Sacromonte. Claro que, como sabemos, ello significaba traducirlos al gusto muy cristiano del arzobispo. Y traducciones plenas de cristianismo eran las de Miguel de Luna. Tan cristianas que algunas voces plantearon sin mucho disimulo reparos acerca de su actuación traslaticia, pese a que Pedro de Castro le defendió hasta después de la muerte del morisco.

Los traductores moriscos en medio cristiano simbolizaban un poco la proteica presencia de la lengua árabe en la sociedad española del siglo XVI. Esquivando a veces la relación que muchos hacían entre lengua árabe y creencia islámica, que muchos moriscos negaban - y que en el caso de Luna resultó ser cierta-, sus competencias en la lengua árabe les hacía importantes a la hora de aprehender la historia, la política o la religión.
En ellos finalizaba una tradición secular de manejo de textos árabes y ellos protagonizaban el proceso de verterlos al castellano. Ellos asimismo vieron cómo cada vez más cristianos viejos empezaban a compartir ese espacio de traducción e interpretación de una lengua que sentían como suya, seguramente tanto los que la seguían usando como los que habían dejado de hacerlo. El árabe estaba pasando de ser una lengua propia a serlo foránea por la vía de primero hacerla clandestina y después sacarla de la Península. Tardará bastante en recuperar su espacio.

De esta forma puede comprobarse cómo el árabe y sus traducciones en el siglo XVI español representan bastante bien algunas de las características más propias del país que se alejaba de ciertas tradiciones medievales y se adentraba en el estado moderno. De la presencia reglada y naturalizada del árabe como lengua de las comunidades mudéjares se pasa en el siglo XVI a la conflictividad de su presencia, pero al mismo tiempo a la necesidad de su traducción como medio de conocimiento y de persuasión. En este tránsito las traducciones del árabe, protagonizadas por actores y motivos diversos, ocupan un espacio que representa el peso que aún tiene la ya antigua lengua en España. Este espacio se irá angostando poco a poco, hasta el punto de que a mitad del siglo XVII ya será dificultoso encontrar traductores de árabe. Pero todavía el siglo Xvi nos ofrece unas dinámicas de relación con el árabe que abarcan todo un universo de opciones de traducción que merece la pena seguir estudiando.

\section{REFERENCIAS BIBLIOGRÁFICAS}

Abad Merino, Mercedes (1997): «La ejecución de la política lingüística de la corona de Castilla durante el siglo Xvı o "no hablar algaravia so pena de çien açotes"», en Pilar Díez de Revenga Torres y José María Jiménez Cano (eds.), Estudios de 
150 Sociolingüistica II. Sincronía y Diacronía, Murcia: Diego Marín Editor, 9-34.

Abad Merino, Mercedes (2003): «Exeas y alfaqueques: aproximación a la figura del intérprete de árabe en el período fronterizo (s. XIII-XV)», en $\mathrm{Ho}$ menaje al profesor Estanislao Ramón Trives, Murcia: Universidad de Murcia, 1, 35-50.

Abad Merino, Mercedes (2005a): «"Aquí hay necesidad de persona capaz en muchas lenguas”. El oficio de intérprete en las últimas fronteras de Castilla», Tonos: Revista Electrónica de Estudios Filológicos, 10 [URL: http: //www. um.es/tonosdigital/].

Abad Merino, Mercedes (2005b): «Intérpretes latentes y patentes en el periodo morisco (1501-1568). Del medio oral al medio escrito», Miscelánea Medieval Murciana, 29-30, 9-23.

Abad Merino, Mercedes (2008): «El intérprete morisco. Aproximación a la historia de la traducción cotidiana en España en el ocaso de la Edad Media», Hermēneus. Revista de Traducción e Interpretación, 10, 1-21.

Abad Merino, Mercedes (2011): «La traducción de cartas árabes en un pleito granadino del siglo XVI. El fenómeno del romanceado como acto judicial: Juan Rodríguez y Alonso del Castillo ante un mismo documento», Al-Qanțara 32/2, 481-518.

Abad Merino, Mercedes y Juan Francisco Jiménez Alcázar (2001): «"Item si sabe...”. El testigo morisco en los pleitos civiles castellanos», en María Jesús Rubiera (coord.), Carlos V. Los moriscos y el islam, Alicante: Universidad de Alicante, 27-38.

Arias Torres, Juan Pablo (1998): «Apuntes para una historia de la traducción del Corán al español», TRANS. Revista de Traductología, 2, 173-176.

Arias Torres, Juan Pablo (2007): «Bibliografía de las traducciones del Corán en el ámbito hispano», TRANS. Revista de Traductología, 11, 261-272.

Arias Torres, Juan Pablo (2016): Reseña de LópezMorillas, Consuelo. El Corán de Toledo. Edición y estudio del manuscrito 235 de la Biblioteca de Castilla La Mancha, Miscelánea de Estudios Árabes y Hebraicos, 65, 233-246.

Arias Torres, Juan Pablo (2020): «Traducir al Uno: de la palabra a la imagen», Al-Qanțara, 41/1, 51-68.

Arias Torres, Juan Pablo y Manuel C. Feria García (2004): «Escrituras árabes granadinas romancea- das: una mina a cielo abierto para la historia de la traducción y la traductología», TRANS. Revista de Traductología, 8, 179-186.

Azcona, Tarsicio de (1964): Isabel la Católica, Madrid: Biblioteca de Autores Cristianos.

BARCELÓ, Carmen (1989): Un tratado medieval catalán de derecho islámico: El Llibre de la Çuna e Xara dels Moros, Córdoba: Universidad de Córdoba.

BARCELó, Carmen y Ana Labarta (2009): Archivos moriscos Textos árabes de la minoría islámica valenciana 1401-1608, València: Publicacions de la Universitat de València, 2009.

Benítez SÁnchez-Blanco, Rafael (2002): «De Pablo a Saulo: traducción, crítica y denuncia de los libros plúmbeos por el P. Ignacio de las Casas, S. J.», AlQanțara, 23/2, 404-436.

BERnABÉ Pons, Luis F. (2004a): «Interferencias entre el árabe y el romance en los textos coránicos aljamiados», en Pedro Bádenas de la Peña, Sofía Torallas Tovar, Eugenio R. Luján y María Ángeles Gallego (eds.), Lenguas en Contacto: El testimonio escrito, Madrid: CSIC, 109-126.

Bernabé Pons, Luis F. (2004b): «De aljamía lejana: la literatura de los moriscos en el exilio», en Ignacio Ceballos Viro y Raquel Suárez García (eds.), Aljamías. In Memoriam Álvaro Galmés de Fuentes y Iacob M. Hassán, Gijón: Trea.

Bernabé Pons, Luis F. (2009): «"Por la lengua se conoce la nación”. Los moriscos y sus idiomas», Alborayque: Revista de la Biblioteca de Extremadura, 3, 107-125.

Bernabé Pons, Luis F. (2009): «Los mecanismos de una resistencia: los libros plúmbeos del Sacromonte y el Evangelio de Bernabé», Al-Qanțara, 23/2, 477-498.

Cabanelas, Darío (1965): El morisco granadino Alonso del Castillo, Granada: Patronato de la Alhambra.

CÁCERES WÜRSIG, Ingrid (2004a): Historia de la traducción en la administración y en las relaciones internacionales en España (s. XVI-XIX), Soria: Vertere, 2004.

CÁCERES WÜRSIG, Ingrid (2004b): «Breve historia de la secretaría de interpretación de lenguas», Meta, 49/3, 609-628. https://doi.org/10.7202/009381ar

CARBONELl i CoRTÉs, Ovidi (1999): Traducción y cultura. De la ideología al texto, Salamanca: Universidad de Salamanca. 
Carmona, Alfonso (1992): «Textos jurídico-religiosos islámicos de las épocas mudéjar y morisca», Áreas, 14, 15-26.

Casassas Canals, Xavier (2015): «El Alcorán de Bellús: un Alcorán mudéjar de principios del XVI con traducciones y comentarios en catalán, castellano y latín», Alhadra, 1, 155-178.

CASTILlo, Alonso del (1852): Sumario y recopilación de todo lo romaçado desde antes de la Guerra del Reyno de Granada, y en ella y después que se acabó, hasta la conclusión de esta recopilación, año 1575. Recopilada por orden y mandato del Sr. Don Pedro de Deça, Presidente de la Real Audiencia de la Ciudad de Granada, Madrid: Real Academia de la Historia

Chiru, Dānīela Corina (2013a). «Traducerile coranice aljamiado-morisce si problematica identificării originalului arab», en Iulian Boldea (ed.), Studies on Literature, Discourse and Multicultural Dialogue, Târgu-Mureș: Arhipeleag, 406-419.

CHIRU, Dānīela Corina (2015): Influențe lingvistice din arabă în traducerile coranice aljamiado-morisce, Universidad de Bucarest, tesis doctoral inédita.

CResPo Muñoz, Francisco Javier (2005): «Acercamiento al estudio de una figura significativa de la sociedad granadina del siglo xvI: "yntérpretes", "trujamanes", "romançeadores"», Revista del Centro de Estudios Históricos de Granada y su Reino, 17, 217-237.

ECHEVARRÍA, Ana y Rafael Mayor (2010): «Las actas de reunión de una cofradía islámica de Toledo, una fuente árabe para el estudio de los mudéjares castellanos», Boletín de la Real Academia de la Historia, 207/3, 257-293.

EpalzA, Míkel de (1986): «Un manuscrito normativo árabe y aljamiado: Problemas lingüísticos, literarios y teológicos de las traducciones moriscas», en Abdeljelil Temimi (ed.), Actes de la première Table Ronde du C.I.E.M. sur La Littérature aljamiadomorisque: hybridisme linguistique et univers discursif, Túnez: Université de Tunis, 35-45.

Epalza, Míkel de (1990): «Le lexique religieux des Morisques et la littérature aljamiadomorisque», en Louis Cardaillac (dir.), Les Morisques et l'Inquisition, Paris, Publisud, 51-64.

Epalza, Míkel de (1995): «La voz oficial de los musulmanes hispanos, mudéjares y moriscos, a sus autoridades cristianas: cuatro textos, en árabe, en castellano y en catalán-valenciano», Sharq Al-

Andalus. Estudios Mudéjares y Moriscos, 12, 279-298.

Feria García, Manuel C. (2001a): La traducción fehaciente del árabe: fundamentos históricos, jurídicos y metodológicos, Universidad de Málaga, 2001, tesis doctoral inédita.

Feria García, Manuel C. (2001b): «Los moriscos y el uso de la aljamía», Al-Andalus-Magreb, 8-9, 299-323.

Feria García, Manuel C. y Juan Pablo Arias Torres (2005): «Un nuevo enfoque en la investigación de la documentación árabe granadina romanceada (ilustrado con dos traducciones inéditas de Bernardino Xarafí, escribano y romanceador del reino de Granada)», Al-Qantara, 26/1, 191-247.

FLoristán, José Manuel (2013): «Diego de Urrea (c. 1559- octubre de 1616), traductor de árabe, turco y persa en la corte de España: Nuevas noticias biográficas», Boletín de la Real Academia de la Historia, 210/2, 227-273.

Folgado García, Jesús R. (2015): «Un intento de diálogo en la Granada nazarí: El arte para ligeramente saber la lengua aráviga de Pedro de Alcalá», Hispania Sacra, 67/135, 49-59.

GALÁN SÁNCHEZ, Ángel (2016), «Identidad e intermediarios culturales. La lengua árabe y el fisco castellano tras la conquista del reino de Granada», Edad Media. Revista de Historia, 19, 107-132.

GALLEGo y BuRín, Antonio y Alfonso Gámir Sandoval (1996): Los moriscos del reino de Granada según el sínodo de Guadix de 1554, Granada, 1968. Reed. facs. Granada: Universidad de Granada. Estudio preliminar de Bernard Vincent

García-Arenal, Mercedes (2010a): «Musulmanes arabófonos y musulmanes aljamiados», AlQantara, 31/1, 295-310.

García-Arenal, Mercedes (2010b): «Miguel de Luna y los moriscos de Toledo: "no hay en España mejor moro"», Chronica Nova, 36, 253-263.

García-Arenal, Mercedes y Fernando Rodríguez Mediano (2002): «Diego de Urrea y algún traductor más: en torno a las versiones de los “plomos”», Al-Qanțara, 23/2, 499-516

García-Arenal, Mercedes y Fernando Rodríguez Mediano (2010): Un Oriente español: los moriscos y el Sacromonte en tiempos de Contrarreforma, Madrid: Marcial Pons. 
152 García-Arenal, Mercedes y Katarzyna K. Starczewska, Katarzyna K. (2014): " "The Law of Abraham the Catholic”: Juan Gabriel as Qur'ān Translator for Martín de Figuerola and Egidio da Viterbo», $A l$ Qanțara, 35/2, 409-459.

García-Arenal, Mercedes y Gerard Wiegers (1999): Entre el islam y el occidente. Vida de Samuel Pallache, judío de Fez, Madrid, Siglo Veintiuno.

García PedraZA, Amalia (2002): Actitudes ante la muerte en la Granada del siglo XVI. Los moriscos que quisieron salvarse, Granada: Universidad de Granada.

Gayangos, Pascual de (1853): Leyes de Moros y Suma de los principales mandamientos y devedamientos de la Ley y Çunna, por Iça ben Gebir, Memorial Histórico Español, 5, 11421.

Gilbert, Claire (2018): «Transmission, Translation, Legitimacy and Control: The Activities of a Multilingual Scribe in Morisco Granada», en Giuseppe Mandalà e Iinmaculada Pérez Marín (eds.), Multilingual and Multigraphic Manuscripts and Documents of East and West, Piscataway, N. J.: Gorgias Press, 425-462.

GILBERT, Claire (2020): In Good Faith: Arabic Translation and Translators in Early Modern Spain, Filadelfia: University of Pennsylvania Press.

Godoy AlCÁntara, José (1981 [1868]): Historia crítica de losfalsos cronicones, Madrid, Tres catorce diecisiete (ed. original, Madrid, Rivadeneyra, 1868).

HAGEDORN, Hans Christian (2006): La traducción narrada. El recurso narrativo de la traducción ficticia, Cuenca, Universidad de Castilla-La Mancha, 2006.

Hagerty, Miguel José (1980): Los libros plúmbeos del Sacromonte, Madrid: Editora Nacional.

HAGERTY, Miguel José (1991): «La traducción interesada: el caso del Marqués de Estepa y los libros plúmbeos», Homenaje al prof. Jacinto Bosch Vilá, Granada: Universidad de Granada, 2, 1179-1186.

Harvey, Leonard P. y Gerard Wiegers (1996): «The Translation from Arabic of the Sacromonte Tables and the Archbishop of Granada: an illuminating correspondence», Qurtuba. Estudios andalusíes, 1, 59-78.

Koningsveld, Pieter Sjoerd van y Grard Albert Wiegers, Gerard Albert (2019): El Pergamino y los Libros Plúmbeos del Sacromonte. Edición Crítica de los Tex- tos Árabes y Análisis de las Ideas Religiosas en Ellos. Presentación de un proyecto de investigación holandés, Granada, 19 de marzo de 2019, trad. M. Colominas Aparicio, Rijswijk: Uitgeverij Avondrood.

LABARTA, Ana (1982): «Notas sobre algunos traductores de árabe en la Inquisición valenciana (1565-1609)», Revista del Instituto Egipcio de Estudios Islámicos, 21, 101-133.

LLopIs MENA, Isabel (2016): Teoría política árabe y persa en la corte de Felipe III: La Doctrina Phísica y Moral de Príncipes de Francisco de Gurmendi, Universidad de Alicante, tesis doctoral inédita.

LóPEZ-Morillas, Consuelo (1982): The Qur'an in SixteenthCentury Spain: Six morisco versions of Sura 79, Londres, Tamesis Books.

LóPEZ-Morillas, Consuelo (1990): «Hispano-Semitic Calques and the Context of Translations», Bulletin of Hispanic Studies, 67, 111-128.

López-Morillas, Consuelo (2011): El Corán de Toledo. Edición y estudio del manuscrito 235 de la Biblioteca de Castilla-La Mancha, Gijón: Trea

LópeZ-Morillas, Consuelo (2012): «Secret Muslims, Hidden Manuscripts: Spanish Translations of the Qur'ān from the Fifteenth to the Seventeenth Centuries», en Reinhold F. Glei (ed.), Frühe Koranübersetzungen. Europäische und außereuropäische Fallstudien, Trier: WVT Wissenschaftlicher Verlag, 99-116.

LunA, Miguel de (2001 [1592]): Historia verdadera del rey don Rodrigo, ed. facsimilar, estudio preliminar Luis F. Bernabé Pons, Granada: Universidad de Granada (ed. original, René Rabut, 1592)

MiLler, Kathryn (2008): Guardians of Islam: Religious authority and Muslim communities of Late Medieval Spain, Nueva York: Columbia University.

Montaner Frutos, Alberto (1988): «Aproximación a una tipología de la literatura aljamiadomorisca aragonesa», en Destierros Aragoneses. I. Judios y moriscos, Zaragoza: Institución Fernando el Católico, 313326.

Montoza Coca, Manuel (2018): Los Sermones de don Martín García, obispo de Barcelona: edición y estudio, Barcelona: Universitat Autònoma de Barcelona, tesis doctoral inédita.

Peña Martín, Salvador (2005): «Narrativa de la traducción», TRANS. Revista de traductología, 9, 99-114. 
Peña Martín, Salvador y Miguel Vega Martín, Miguel (2001): «Reverencia», Trujamán. Revista diaria de Traducción, 10/08/2001 <https://cvc.cervantes.es/ trujaman/anteriores/agosto01/10082001.htm>.

Pérez de Ayala, Martín (1911 [1566]): Doctrina Christiana en lengua arábiga y castellana compuesta e impresa por mandato del Ilustrísimo y Reverendísimo Señor D. Martín Pérez de Ayala, ed. facsimilar, Valencia, Imprenta Hijos de F. Vives Mora (ed. original: Valencia: Ioan Mey).

PéReZ de Hita, Ginés (1595): Historia de los vandos de los Zegríes y Abencerrajes, caballeros moros de Granada, de las guerras civiles que hubo en ella, Zaragoza: Miguel Ximeno Sánchez, 1595.

Pezzi, Elena (1987): «El problema de la confesión de moriscos en Pedro Alcalá», en Homenaje al profesor Darío Cabanelas Rodríguez, O.F.M., con motivo de su LXX aniversario, Granada: Universidad de Granada, 1, 433-444.

Resines, Luis (1994): «Los catecismos del Xvi y su modo de presentar la fe», Archivo de Historia de la Iglesia, 3, 197-213.

Ribera y TARragó, Julián (1928): «La enseñanza entre los musulmanes españoles», Disertaciones $y$ Opúsculos. Edición colectiva que en su jubilación del profesorado le ofrecen sus discípulos y amigos (18871927), Madrid: Imprenta de Estanislao Mestre, 1, 229359.

RICARD, Robert (1928): "Remarques sur l'Arte et le Vocabulista de Fr. Pedro de Alcalá», en Mémorial Henri Basset, París: Publications de l'Institut des Hautes Études Marocaines, 2, pp. 229-236.

Rотн, Ulli (2014): «La traducción del Corán de Juan de Segovia», Al-Qanțara, 35/2, 555-578.

Rubiera Mata, María Jesús (1995): «Los textos epigráficos de los palacios nazaríes (algo más que una escritura)», Arte islámico en Granada. Propuesta para un Museo de la Alhambra, Granada, 96-105.

SAlicrú i Lluch, Roser (2005): «Más allá de la mediación de la palabra: negociación con los infieles y mediación cultural en la baja Edad Media», en María Teresa Ferrer i Mallol, Jean-Marie Moeglin, Stéphane Péquignot y Manuel Sánchez Martínez (eds.), Negociar en la Edad Media, Barcelona: CSIC, 409-440.
SARmiento Pérez, Marcos (2015): «Traducir y calificar para la Inquisición», en Gisela Marcelo Wirnitzer (ed.), Traducir la Historia desde diferentes Prismas, Las Palmas de Gran Canaria: Servicio de Publicaciones y Difusión Científica de la Universidad de Las Palmas de Gran Canaria, 37-97.

SARMIENTo PéreZ, Marcos (2016): «Interpreting for the Inquisition», en Kayoko Takeda y Jesús Baigorri-Jalón (eds.), New Insights in the History of Interpreting, Ámsterdam-Filadelfia: Johns Benjamins, 47-73.

SARmiento Pérez, Marcos (2018): «El intérprete en la confesión sacramental en la Iglesia católica, con especial atención a la España de los siglos XVI y XVII». Culture \& History Digital Journal, 7/11.

Schaub, Jean-Frédéric (1999): Les Juifs du roi d'Espagne, París: Hachette.

ScotTo, Davide (2012): «"De Pe a Pa”. Il Corano trilingue di Juan de Segovia (1456) e la conversione pacifica dei Musulmani», Rivista di Storia $e$ Letteratura Religiosa, 48, 3, 515-577.

Soto GonzÁLEZ, Teresa y Katarzyna K. Starczewska (2016): «Authority, Philology and Conversion under the Aegis of Martín García», en Mercedes García-Arenal (ed.), After Conversion: Iberia and the Emergence of Modernity, Leiden: Brill, 199-228.

SzPIECH, Ryan (2012): «Preaching Paul to the Moriscos: The Confusión o confutación de la secta mahomética y del Alcorán (1515) of Juan Andrés», La Corónica, 41, 317-343.

Torres Palomo, María Paz (1971): Bartolomé Doradory el árabe dialectal andaluz, Granada: Universidad de Granada, resumen de tesis doctoral.

VAlencia, Pedro de (1999): Obras Completas, vol IV, 2, estudio introductorio de G. Morocho Gayo, León: Universidad de León.

ViguerA, María Jesús (1990): «Sobre manuscritos mudéjares: Documentos fechados en Aragón entre los siglos $6^{\circ}-10^{\circ}$ de la Hégira (XII-XVI d. J. C.)», Manuscrits Arabes en Occident Musulman. Etat des collections et perspectives de recherche, Casablanca, 1990, 15-24.

VIgUeRA, María Jesús (2016): Los manuscritos árabes en España: su Historia y la Historia. Discurso leído el día 28 de febrero de 2016 en el acto de su recepción pública por la Excma. Sra. da. María Jesús Viguera Molins, Madrid, Real Academia de la Historia, 2016. 
154 WIEGERS, Gerard (1994): Islamic Literature in Spanish and Aljamiado. Yça of Segovia (fl. 1450), his Antecedents and Successors, Leiden: Brill.

ZANón, Jesús (1995): «Los estudios de lengua árabe entre los moriscos aragoneses a través de los manuscritos de la Junta», Sharq Al-Andalus. Estudios Mudéjaresy Moriscos, 12, 363-374.

ZwARTJES, Otto (2014): «Algunas observaciones sobre el Vocabulista arauigo en letra castellana (1505) de Pedro de Alcalá y el Vocabulario español-latino (c. 1495) de Antonio de Nebrija», en María Luisa Calero, Alfonso Zamorano, F. Javier Perea, María del Carmen García Manga, María Martínez-Atienza (eds.), Métodos y resultados actuales en Historiografía de la Lingüistica, Münster: Nodus Publikationen. 